\title{
COMPARISON OF HEARING THRESHOLD ESTIMATION USING AUDITORY STEADY STATE RESPONSES AND BRAINSTEM AUDITORY EVOKED POTENTIALS IN CHILDREN
}

\author{
Slobodanka Lemajić-Komazec, Zoran Komazec, Maja Buljčik Čupić, \\ Saša Knežević and Oliver Vajs
}

University of Novi Sad, Faculty of Medicine, Department of Ear, Nose and Throat Diseases, Clinical Center of Vojvodina, Novi Sad, Vojvodina, Republic of Serbia

\begin{abstract}
SUMMARY - Current recommendations proposed by pediatric audiologists are to commence with hearing amplification in children aged 6 months and above, after previous determination of the type and degree of hearing impairment and audiometric configuration. The goal of this study was to compare results obtained by click-evoked auditory brainstem response (c-ABR) and auditory steady state response (ASSR) in a group of children. This study included 68 children with different degrees of hearing impairment evaluated by c-ABR and ASSR. It is well-known that the c-ABR threshold highly correlates with behavioral hearing level at $2 \mathrm{kHz}$. In our study, the correlation between the cABR and ASSR thresholds in the whole sample was $0.58,0.73,0.97,0.96,0.95,0.97$; in the group of children with c-ABR thresholds up to $40 \mathrm{dBHL}$, it was $0.42,0.73,0.86,0.74,0.81,0.81$; and in the group with c-ABR thresholds worse than $40 \mathrm{dBHL}$, it was $0.46,0.56,0.89,0.83,0.85,0.89$ at $0.5,1$, $2,4,1-4,2-4 \mathrm{kHz}$, respectively. Individual differences between the c-ABR and ASSR thresholds in the whole sample were up to $95,90,20,25 \mathrm{~dB}$ at $0.5,1,2,4 \mathrm{kHz}$, respectively. Study results indicated that there was strong correlation between the c-ABR and ASSR thresholds at 2, 4, 1-4, 2-4 kHz. The ASSR can be used as a valuable clinical tool and an excellent complementary method which, along with other audiologic techniques, provides more accurate hearing threshold estimation at an early age in children.
\end{abstract}

Key words: Evoked potentials, auditory; Audiometry; Hearing loss

\section{Introduction}

With the introduction of the Universal Newborn Hearing Screening Program (UNHSP), which provides early detection of hearing impairment in children, hearing evaluation techniques have significantly changed. Nowadays, it is necessary to diagnose the type and degree of hearing impairment, as well as con-

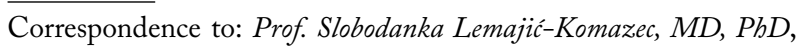
University of Novi Sad, Faculty of Medicine, Department of Ear, Nose and Throat Diseases, Clinical Center of Vojvodina, Hajduk Veljkova 1-9, Novi Sad, Vojvodina, Republic of Serbia E-mail: slobodanka.lemajic-komazec@mf.uns.ac.rs Received November 7,2016, accepted August 31, 2017 figuration of hearing loss in children up to 3 months of age, in order to start early treatment and provide adequate hearing aid by the age of 6 months ${ }^{1,2}$. Early detection of hearing impairment in newborns and infants is important in order to achieve linguistic competences and language development in deaf and hearing impaired children. Children whose treatment starts at a late age may encounter problems in communication, cognition, reading, understanding and social-emotional development ${ }^{3,4}$. Recommendations of the UNHSP represent a great challenge to audiologists, since definitive diagnosis of hearing impairment in infants and children is based on several subjective and objective tests, all of which have limitations. 
For decades, the most reliable objective diagnostic method in pediatric audiology was click-evoked auditory brainstem response (c-ABR) with a non-filtered click as stimulus. There is empirical confirmation that a non-filtered click c-ABR highly correlates with an average hearing threshold determined by pure tone audiometry in $2-4 \mathrm{kHz}$ range $\mathrm{e}^{5-9}$. Unfortunately, estimation of c-ABR threshold does not provide information on hearing threshold below $2 \mathrm{kHz}$. Having in mind that hearing impaired children in most cases have better hearing ability at lower frequencies, this technical limitation of c-ABR significantly affects the objective hearing status in the area of speech frequency. In order to provide children with hearing impairment adequate hearing amplification, it is of utmost importance to evaluate hearing at low frequencies. In this case, the disadvantage of c-ABR is compensated by behavioral assessment of hearing which is, however, unreliable in infants under 3 months of age. Attempts to provide objective diagnosis in the entire hearing area using tone-evoked ABR were never put in day-to-day clinical practice due to unstable wave morphology, duration of the test, and lack of response in cases with severe and profound hearing impairment ${ }^{10-12}$.

Therefore, the auditory steady-state response (ASSR) has been greatly welcomed as an appropriate alternative to behavioral audiometry. Unlike the use of broad-band click or tone burst in ABR, the ASSR uses continuous amplitude and frequency modulated tone as stimulus. Compared to c-ABR, interpreted subjectively and relying greatly on audiologist's experience, the ASSR finding is a result of statistical analysis of the probability of response. In theory, results of the ASSR should be automatic hearing threshold estimation at speech frequencies, requiring no special training for interpretation. In recent years, there have been many studies on the correlation among ASSR, c-ABR and tone-audiometry in adults and children. Despite the fact that most authors confirm the correlation between an average hearing threshold determined by tone audiometry and ASSR, there have been single cases indicating discrepancies even exceeding $30 \mathrm{~dB}$ in hearing thresholds between these two methods ${ }^{13}$. Moreover, it has been published that hearing threshold estimation by ASSR is most reliably done in patients with mild or moderate hearing impairment, whereas most discrepancies in hearing thresholds, determined by pure tone audiometry, have been diagnosed in subjects with normal hearing ${ }^{14,15}$.
The goal of this study was to compare hearing thresholds obtained by the c-ABR and ASSR within a group of children with different levels of hearing impairment.

\section{Patients and Methods}

The study protocol was approved by the local Ethics Committee, and informed consent, signed by parents, was required for every subject before they could participate. The current study was conducted from January 2014 to December 2015. It included 68 children (136 ears) with suspected hearing impairment. All examinees underwent an ENT examination, tympanometry, transient evoked otoacoustic emissions, cABR, ASSR, and behavioral hearing estimation conducted by experienced pediatric audiologists. The children with conductive hearing loss and the children in whom the fifth wave on $\mathrm{c}-\mathrm{ABR}$ at stimulus intensity of $100 \mathrm{dBHL}$ could not be recorded were excluded from the study. The mean age of children with different estimated hearing thresholds was $26.6 \pm 19$ months SD (8-120 months), out of which 49 were boys and 19 girls. According c-ABR threshold, the children were divided into two groups. Out of 136 examined ears, 26 had c-ABR threshold of up to $40 \mathrm{dBHL}$, and 110 ears were diagnosed with hearing impairment above 40 dBHL. The mean age in the group with c-ABR threshold up to $40 \mathrm{dBHL}$ was $24.1 \pm 7.7$ months SD (11 boys and 2 girls), one child had Down syndrome and another one was blind. In the group with c-ABR threshold above $40 \mathrm{dBHL}$, the mean age was $27.2 \pm 20.8$ months SD (38 boys and 17 girls).

The c-ABR recording was conducted under general anesthesia (ketamine) using an Interacoustics Eclipse EP 25 system. A non-filtered rarefied polarity click was used as stimulus with repetition rate of 27.7/s. The click was emitted over inserted earphones calibrated at hearing level. The recording electrodes were positioned on both mastoids (Reference), on the forehead (Active) and on the lower part of the forehead (Ground). Impedance for all electrodes was 3 $\mathrm{k} \Omega \mathrm{hm}$ or less. The analysis window was $20 \mathrm{~ms}$, while low and high filters were 100 and $3000 \mathrm{~Hz}$. The measurement was conducted by a descending method, starting from the hearing threshold estimated by a behavioral method. The responses were recorded with accuracy of $5 \mathrm{~dB}$ with maximum intensity of $100 \mathrm{dBHL}$. 
Table 1. Mean c-ABR and ASSR thresholds in $A B H L(N=136$, ears)

\begin{tabular}{|l|l|l|l|l|l|}
\hline Group & c-ABR & ASSR 0.5 kHz & ASSR 1 kHz & ASSR 2 kHz & ASSR 4 kHz \\
\hline Whole sample & & & & & \\
Mean & 74.4 & 59 & 62.6 & 73.3 & 71.1 \\
SD & 28.1 & 34.2 & 33.7 & 29.2 & 32.4 \\
$\mathrm{n}$ & 136 & 136 & 136 & 126 & 118 \\
\hline $\mathrm{c}-\mathrm{ABR} \leq 40 \mathrm{dBHL}$ & & & & & \\
Mean & 24 & 28.6 & 22.3 & 22.8 & 16.1 \\
$\mathrm{SD}$ & 5.7 & 19.1 & 12.6 & 6.3 & 9.6 \\
$\mathrm{n}$ & 26 & 26 & 26 & 26 & 26 \\
\hline $\mathrm{c}-\mathrm{ABR}>40 \mathrm{dBHL}$ & & & & & \\
Mean & 86.2 & 66.1 & 72.1 & 86.4 & 87 \\
SD & 14.8 & 33.1 & 29.8 & 15.1 & 15.2 \\
$\mathrm{n}$ & 110 & 110 & 110 & 100 & 92 \\
\hline
\end{tabular}

$\mathrm{c}-\mathrm{ABR}=$ click-evoked auditory brainstem response; ASSR = auditory steady state response

The measurements were done for the right ear first, and then for the left one. The criterion used to evaluate the response was visual identification of wave $V$ and its reproducibility. The evaluation was conducted by experienced audiologists.

Upon c-ABR threshold estimation, measurements continued with ASSR using the same equipment. The recording continued with the change of signal by using binaural amplitude and frequency modulated tones of $0.5,1,2$ and $4 \mathrm{kHz}$ with $90 \mathrm{~Hz}$ modulation rate ${ }^{10,15,16}$. The measurement was conducted by a descending method, where the initial stimulation intensity depended on estimated c-AEP hearing threshold and behavioral hearing evaluation. The accuracy of measurements was at $5 \mathrm{~dB}$ and the maximum stimulus intensity was $100 \mathrm{dBHL}$. The recorded response represented statistical analysis of the probability of response at $95 \%$ confidence level. After obtaining results and achieving $100 \%$ reliability of response, it was accepted regarding frequency and intensity, and therefore we moved to lower intensity stimulation. The estimated threshold provided by the manufacturer criteria was considered as the ASSR threshold. According to default criteria, the measurements took 6 minutes per frequency and intensity. In case the examiner estimated that the time of response recording should be prolonged, it was done in 10 minutes.

Statistical analysis was conducted by SPSS 17 program, which provided mean values of the c-ABR and ASSR thresholds, mean and individual difference thresholds determined by c-ABR and ASSR, as well as Pearson coefficient of correlation between thresholds determined by c-ABR and ASSR at $0.5,1,2,4$, 1-4, 2-4 kHz. Statistical methods were applied to both groups, i.e. the one with normal hearing, slight or mild hearing impairment (estimated behavioral hearing threshold up to $40 \mathrm{dBHL}$ ) and the group with hearing impairment exceeding $40 \mathrm{dBHL}$.

\section{Results}

The mean hearing level determined by behavioral audiometry and c-ABR in the whole sample (136 ears) was $74.4 \mathrm{dBHL}$, SD $28.1 \mathrm{~dB}$ (5-100 dBHL).

The mean ASSR thresholds were 59, 62.6, 73.3, 71.1, 70.7, $72.6 \mathrm{dBHL}$ at $0.5,1,2,4,1-4,2-4 \mathrm{kHz}$, respectively. The mean differences between the c-ABR and ASSR thresholds were 15.4, 11.8, 1.1, 3,3, 3.7, 1.8 $\mathrm{dB}$ at $0.5,1,2,4,1-4,2-4 \mathrm{kHz}$, respectively. The mean c-ABR and ASSR thresholds are shown in Table 1.

Individual differences between the c-ABR and ASSR thresholds in absolute values were up to 95,90 , $20,25 \mathrm{~dB}$ at $0.5,1,2,4 \mathrm{kHz}$, respectively. The mean difference between the c-ABR and ASSR thresholds of up to $10 \mathrm{~dB}$ was measured at $500 \mathrm{~Hz}$ in $59.6 \%$, at $1000 \mathrm{~Hz}$ in $75.7 \%$, at $2000 \mathrm{~Hz}$ in $95.2 \%$ and at 4000 $\mathrm{Hz}$ in $91.5 \%$ of ears.

Individual differences of up to $10 \mathrm{~dB}$ in the group of children with normal hearing, slight or moderate hearing loss were $69.2,88.5,100,73.1 \%$ at $0.5,1,2,4$ 
Table 2. Individual difference between $c-A B R$ and $A S S R$ thresholds in $d B$

\begin{tabular}{|l|l|l|l|l|}
\hline Group & $0.5 \mathrm{kHz}$ & $1 \mathrm{kHz}$ & $2 \mathrm{kHz}$ & $4 \mathrm{kHz}$ \\
\hline Whole sample & & & & \\
$0-10 \mathrm{~dB}$ & $81(59.6 \%)$ & $103(75.7 \%)$ & $120(95.2 \%)$ & $108(91.5 \%)$ \\
$15-25 \mathrm{~dB}$ & $26(19.1 \%)$ & $11(8.1 \%)$ & $6(4.8 \%)$ & $10(8.5 \%)$ \\
$>30 \mathrm{~dB}$ & $29(21.3 \%)$ & $22(16.2 \%)$ & $0(0 \%)$ & $0(0 \%)$ \\
$\mathrm{n}$ & 136 & 136 & 126 & 118 \\
\hline $\mathrm{c}-\mathrm{ABR} \leq 40 \mathrm{dBHL}$ & & & & \\
$0-10 \mathrm{~dB}$ & $18(69.2 \%)$ & $23(88.5 \%)$ & $26(100 \%)$ & $19(73.1 \%)$ \\
$15-25 \mathrm{~dB}$ & $3(11.5 \%)$ & $3(11.5 \%)$ & $0(0 \%)$ & $7(26.0 \%)$ \\
$>30 \mathrm{~dB}$ & $5(19.3 \%)$ & $0(0 \%)$ & $0(0 \%)$ & $0(0 \%)$ \\
$\mathrm{n}$ & 26 & 26 & 26 & 26 \\
\hline $\mathrm{c}-\mathrm{ABR}>40 \mathrm{dBHL}$ & & & & \\
$0-10 \mathrm{~dB}$ & $63(57.3 \%)$ & $80(72.7 \%)$ & $94(94.0 \%)$ & $89(96.7 \%)$ \\
$15-25 \mathrm{~dB}$ & $22(20.0 \%)$ & $8(7.3 \%)$ & $6(6.0 \%)$ & $3(3.3 \%)$ \\
$>30 \mathrm{~dB}$ & $25(22.3 \%)$ & $22(20.0 \%)$ & $0(0 \%)$ & $0(0 \%)$ \\
$\mathrm{N}$ & 110 & 110 & 100 & 92 \\
\hline
\end{tabular}

$\mathrm{c}-\mathrm{ABR}=$ click-evoked auditory brainstem response; ASSR = auditory steady state response

Table 3. Mean difference and correlation between $c-A B R$ and $A S S R$ thresholds in $d B(N=136$, ears)

\begin{tabular}{|l|l|l|l|l|l|l|}
\hline & \multicolumn{7}{|l|}{ ASSR compared to c-ABR thresholds (kHz) } \\
\hline Group & 0.5 & 1 & 2 & 4 & Mean 1-4 & Mean 2-4 \\
\hline Whole sample & & & & & & \\
Mean difference & 15.4 & 11.8 & 1.1 & 3.3 & 3.7 & 1.8 \\
n & 136 & 136 & 126 & 118 & 136 & 126 \\
Pearson coefficient & 0.58 & 0.73 & 0.97 & 0.96 & 0.95 & 0.97 \\
\hline c-ABR $\leq 40$ dBHL & & & & & & \\
Mean difference & 4.6 & 1.7 & 1.2 & 7.9 & 3.4 & 4.7 \\
n & 26 & 26 & 26 & 26 & 26 & 26 \\
Pearson coefficient & 0.42 & 0.73 & 0.86 & 0.74 & 0.81 & 0.81 \\
\hline c-ABR $>40$ dBHL & & & & & & \\
Mean difference & 20.1 & 14.1 & 0.2 & 0.8 & 3.7 & 0.2 \\
n & 110 & 110 & 100 & 92 & 110 & 100 \\
Pearson coefficient & 0.46 & 0.56 & 0.89 & 0.83 & 0.85 & 0.89 \\
\hline
\end{tabular}

c-ABR $=$ click-evoked auditory brainstem response; ASSR = auditory steady state response

$\mathrm{kHz}$, respectively. In the group with estimated c- $\mathrm{ABR}$ threshold worse than $40 \mathrm{~dB}$, individual differences of up to $10 \mathrm{~dB}$ between $\mathrm{c}-\mathrm{ABR}$ and ASSR thresholds were $57.3,72.7,94,96.7 \%$ at $0.5,1,2,4 \mathrm{kHz}$, respectively.

In the total sample, Pearson correlation coefficients between the c-ABR and ASSR thresholds were 0.58,
$0.73,0.97,0.96,0.95,0.97$ at $0.5,1,2,4,1-4,2-4 \mathrm{kHz}$, respectively. The correlation between the c-ABR and ASSR mean thresholds were very high and similar in all subjects. These results are shown in Table 2 .

In the group of children with c-ABR threshold up to $40 \mathrm{dBHL}$, there were 26 ears and the mean $\mathrm{c}-\mathrm{ABR}$ threshold was $24 \mathrm{dBHL}$ (20-40 dBHL). The mean 


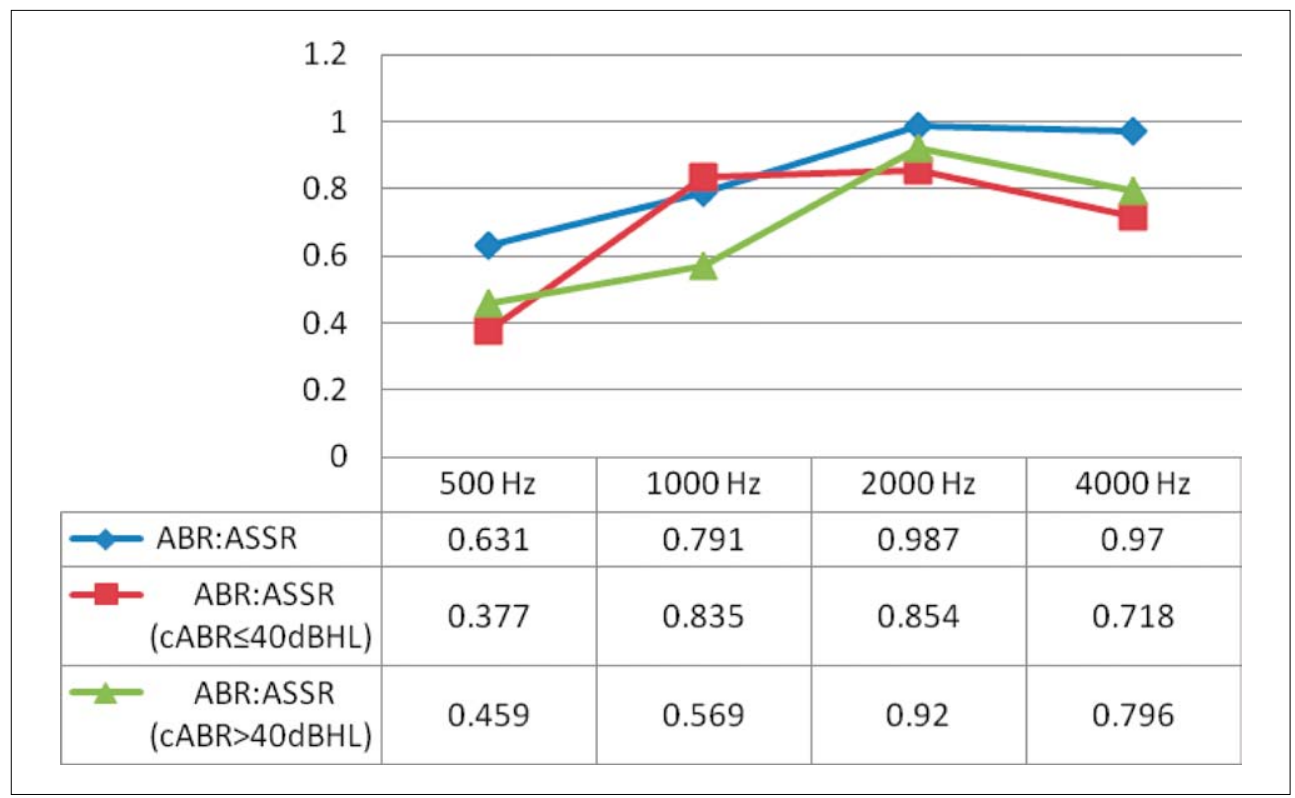

Fig. 1. Correlation between $c-A B R$ and ASSR thresholds at 500-4000 Hz.

$\mathrm{c}-\mathrm{ABR}=$ click-evoked auditory brainstem response; ASSR = auditory steady state response

values of ASSR estimated thresholds were 28.6, 22.3, $22.8,16.1,20.6,19.3 \mathrm{dBHL}$, and differences between the c-ABR and ASSR were 4.6, 1.7, 1.2, 7.9, 3.4, 4.7 $\mathrm{dBHL}$ at $0.5,1,2,4,1-4,2-4 \mathrm{kHz}$, respectively. Individual differences were measured at $0.5 \mathrm{kHz}$ up to 40 $\mathrm{dB}$, at 1 and $2 \mathrm{kHz}$ up to $10 \mathrm{~dB}$, and at $4 \mathrm{kHz}$ up to 15 $\mathrm{dB}$. In this group, Pearson correlation between the cABR and ASSR thresholds was 0.42, 0.73, 0.86, 0.74, $0.81,0.81$ for ASSR at $0.5,1,2,4,1-4,2-4 \mathrm{kHz}$, respectively.

The group with c-ABR threshold worse than 40 $\mathrm{dBHL}$ included 110 ears and the mean c-ABR threshold was $86.2 \mathrm{dBHL}$ (50-100 dBHL). The mean hearing level values estimated by ASSR were 66.1, 72.1, 86.4, 87, 82.5, 86.4 dBHL, and the differences between hearing levels evaluated by c-ABR and ASSR were $20.1,14.1,0.2,0.8,3.7,0.2 \mathrm{~dB}$ at $0.5,1,2,4,1-4$, 2-4 $\mathrm{kHz}$, respectively. Individual differences were measured at $0.5 \mathrm{kHz}$ up to $95 \mathrm{~dB}$, at $1 \mathrm{kHz}$ up to 90 $\mathrm{dB}$, at $2 \mathrm{kHz}$ up to $20 \mathrm{~dB}$, and at $4 \mathrm{kHz}$ up to $35 \mathrm{~dB}$. Mean difference and correlation between c-ABR and ASSR thresholds are shown in Table 3. In the sample with severe hearing loss and deafness, Pearson correlation between c-ABR and ASSR yielded values of 0.46 , $0.56,0.89,0.83,0.85,0.89$ for ASSR at 0.5, 1, 2, 4, 1-4, 2-4 $\mathrm{kHz}$, respectively. Correlation between c-ABR and ASSR thresholds are shown in Figure 1.

\section{Discussion}

At the time of hearing assessment, the average age of children was about 26 months. This unacceptably late hearing assessment is the consequence of a nonexistent UNHSP in Serbia ${ }^{17}$. The mean hearing level in the examined children was 74.4 dBHL (20-100 dBHL).

The mean differences between the c-ABR and ASSR thresholds in the whole sample were 15.4,11.8, $1.1,3,3,3.7,1.8 \mathrm{~dB}$ at $0.5,1,2,4,1-4,2-4 \mathrm{kHz}$, respectively. Similar findings have been reported by Swanepoel and Ebrahim ${ }^{18}$. In our study, the mean ASSR thresholds were better than those obtained with cABR, although in most studies the ASSR threshold was higher than $\mathrm{c}-\mathrm{ABR}^{11,18}$. This may be explained by a large number of examined children with almost normal hearing in the frequency area below $2 \mathrm{kHz}$.

Tolerant individual differences between hearing levels estimated by c-ABR and ASSR of up to 10 dBHL were found in 59.6, 75.7, 95.2, 91.5\% of ears at $0.5,1,2,4 \mathrm{kHz}$, respectively. A difference over $30 \mathrm{~dB}$ was measured in $21.3 \%, 16.2 \%, 0,0 \%$ of ears at $0.5,1$, $2,4 \mathrm{kHz}$, respectively. Individual differences varied from $95 \mathrm{~dB}$ at $0.5 \mathrm{kHz}, 90 \mathrm{~dB}$ at $1 \mathrm{kHz}, 20 \mathrm{~dB}$ at 2 $\mathrm{kHz}$ to $25 \mathrm{~dB}$ at $4 \mathrm{kHz}$. Significant difference found in the low-frequency area was the result of the well- 
known fact that c-ABR determines hearing levels in the medium frequency area, while most children have better hearing thresholds at lower frequencies (steeply sloping high-frequency hearing loss). This study confirmed strong correlation coefficients between hearing levels determined by c-ABR and ASSR at 2 and 4 $\mathrm{kHz}$, as well as the mean 1-4, 2-4 ASSR thresholds $(0.97,0.96,0.95,0.97)$.

On the contrary, at 0.5 and $1 \mathrm{kHz}$ frequencies, a weak/moderate correlation was found. There also are other reports on a high correlation of 0.90 and 0.97 between hearing levels determined by c-ABR and ASSR at 2 and $4 \mathrm{kHz}$, and worse correlation of 0.85 and 0.87 at 0.5 and $1 \mathrm{kHz}^{18-21}$. High correlation in the whole sample was found for the mean ASSR thresholds (1-4 and 2-4 kHz) compared to the c-ABR thresholds. Similar findings have been reported by Swanepoel and Ebrahim ${ }^{18}$.

Having in mind the published research findings, indicating that the greatest errors made with ASSR were in patients with normal hearing, our sample was divided into two groups. The first group included children with c-ABR threshold of up to $40 \mathrm{dBHL}$. In this group, hearing evaluation was performed mostly due to speech and language delay, where in most cases pervasive developmental disorder was found. The mean hearing level in this group was $24 \mathrm{dBHL}$, and the mean differences between c-ABR and ASSR were 4.6, $1.7,1.2,7.9,3.4,4.7 \mathrm{~dB}$ at $0.5,1,2,4,1-4,2-4 \mathrm{kHz}$, respectively. Individual differences in absolute values ranged from under $40 \mathrm{~dB}$ at $0.5 \mathrm{kHz}$ to tolerable $10-$ $15 \mathrm{~dB}$ at other frequencies. Correlation coefficients ranged from 0.42 at $0.5 \mathrm{kHz}$ to 0.86 at $2 \mathrm{kHz}$. The nonsignificantly lower correlation coefficient compared to the entire sample could be explained by higher effects of noise recorded during low intensity stimulation. Recording background noise during ASSR and c-ABR low-level stimulation could explain major differences between the behavioral and electrophysiological thresholds in normal hearing population, as published in numerous studies ${ }^{22-29}$.

The second group included children with moderate, severe or profound hearing loss determined by cABR (50-100 dBHL). Their mean behavioral hearing level was $86.2 \mathrm{dBHL}$. Differences in thresholds determined by c-ABR and ASSR were 20.1, 14.1, 0.2, 0.8, $3.7,0.2 \mathrm{~dB}$ at $0.5,1,2,4,1-4,2-4 \mathrm{kHz}$, respectively. Maximum and individual differences ranged from un- der $20 \mathrm{~dB}$ at $2 \mathrm{kHz}$ to $95 \mathrm{~dB}$ at $0.5 \mathrm{kHz}$. This significant difference could be explained by the fact that the 'ski-slope' type of audiogram was found in 12 ears. Correlation coefficients were significant at all frequencies tested, even though the greatest ones of over 0.80 were noted at $2 \mathrm{kHz}$ and above.

\section{Conclusion}

The use of ASSR is completely justified in pediatric hearing evaluation. High frequency ASSR thresholds significantly correlate with the c-ABR levels in different levels of hearing loss. These results indicate the highest reliability of the ASSR in relation to the cABR 2, 4, 1-4, 2-4 kHz. The ASSR is a very useful complementary method and a diagnostic algorithm in pediatric hearing loss, especially as a cross-check using c-ABR findings, mostly in children where it is not possible to perform an adequate behavioral hearing threshold assessment, especially to detect the residual hearing in children with absent c-ABR and otoacoustic emissions.

\section{References}

1. Joint Committee on Infant Hearing. Year 2007 Position Statement: Principles and Guidelines for Early Hearing Detection and Intervention Programs. Pediatrics. 2007;120:898-921. DOI: $10.1542 /$ peds.2007-2333

2. Marn B, Kekić B. Outcome of the universal neonatal screening in Croatia 2003-2014. Paediatr Croat. 2016;60:9-14. DOI: 10.13112/PC.2016.2

3. Holden-Pitt L, Albertorio Diaz J. Thirty years of the annual survey of deaf and hard of hearing children and youth: a glance over the decades. Am Ann Deaf. 1998;143:72-6. DOI: 10.1353 /aad.2012.0630

4. Moeller MP, White KR, Shisler L. Primary care physicians' knowledge, attitudes, and practices related to newborn hearing screening.. Pediatrics. 2006;178(4):1357-70. DOI: 10.1542/ peds.2006-1008

5. Marttila TI, Karikoski JO. Comparison between audiometric and $\mathrm{ABR}$ thresholds in children. Contradictory findings. Eur Arch Otorhinolaryngol. 2006 May;263(5):399-403. DOI: 10.1007/s00405-005-1019-x

6. Gorga, MP, Johnson TA, Kaminski JR, Beauchaine KL, Garner CA, Neely ST. Using a combination of click- and tone burstevoked auditory brain stem response measurements to estimate pure-tone thresholds. Ear Hear. 2006;27:60-74. DOI:10.1097/ 01.aud.0000194511.14740.9c

7. Linares AE, Costa Filho OA, Martinez MA. Auditory steadystate response in pediatric audiology. Braz J Otorhinolaryngol. 2010;76:723-8. DOI:10.1590/S1808-86942010000600010 
8. Scherf F, Brokx J, Wuyts FL, Van de Heyning PH. The ASSR: clinical application in normal-hearing and hearing-impaired infants and adults, comparison with the click-evoked ABR and pure-tone audiometry. Int J Audiol. 2006;45:281-6. DOI: 10.1080/14992020500485684

9. Laukli E. Frequency specificity and accuracy of ABR and ASSR. Int J Audiol. 2014;53:697-8. DOI: 10.3109/149920 27.2014.905718

10. Canale A, Lacilla M, Cavalot AL, Albera R. Auditory steadystate responses and clinical applications. Eur Arch Otorhinolaryngol. 2006;263:499-503. DOI:10.1007/s00405-006-0017-y

11. Cone-Wesson B, Dowell RC, Tomlin D, Rance G, Ming WJ. The auditory steady-state response: comparisons with the auditory brainstem response. J Am Acad Audiol. 2002;13:173-87. http://www.audiology.org/sites/default/files/journal/JAAA_13 _04_02.pdf

12. Attias J, Buller N, Rubel Y, Raveh E. Multiple auditory steadystate responses in children and adults with normal hearing, sensorineural hearing loss, or auditory neuropathy. Ann Otol Rhinol Laryngol. 2006;115:268-76. DOI: 10.1177/000348940611500404

13. Picton TW, Dimitrijevic A, Perez-Abalo MC, Van Roon P. Estimating audiometric thresholds using auditory steady-state responses. J Am Acad Audiol. 2005;16:140-56. DOI:10.3766/ jaaa.16.3.3

14. Dimitrijevic A, John MS, Van Roon P, Purcell DW, Adamonist J, Ostroff J, Nedzelski JM, Picton TW. Estimating the audiogram using multiple auditory steady-state responses. J Am Acad Audiol. 2002;13:205-24. http://www.audiology.org/sites/ default/files/journa1/JAAA_13_04_04.pdf

15. Komazec Z, Lemajić-Komazec S, Jović R, Nađ Č, Jovančević $\mathrm{Lj}$, Savović S. Comparison between auditory steady-state responses and pure-tone audiometry. Vojnosanit Pregl. 2010; 67:761-5. DOI: 10.2298/VSP1009761K

16. Yeung KN, Wong LL. Prediction of hearing thresholds: comparison of cortical evoked response audiometry and auditory steady-state response audiometry techniques. Int J Audiol. 2007;46:17-25. DOI:10.1080/14992020601102238

17. Lemajić-Komazec S, Komazec Z, Vlaški Lj, Dankuc D. Analysis of reasons for late diagnosis of hearing impairment in children. Med Pregl. 2008;61(Suppl 2):21-5. https://www.researchgate.net/publication/23387970_Analysis_of_reasons_ for_late_diagnosis_of_hearing_impairment_in_children

18. Swanepoel DW, Ebrahim S. Auditory steady-state response and auditory brainstem response thresholds in children. Eur Arch Otorhinolaryngol. 2009;266:213-9. DOI:10.1007/ s00405-008-0738-1

19. Lee HS, Ahn JH, Chung JW, Yoon TH, Lee KS. Clinical comparison of the auditory steady-state response with the click auditory brainstem response in infants. Clin Exp Otorhinolaryngol. 2008;1:184-8. DOI:10.3342/ceo.2008.1.4.184

20. Luts H, Desloovere C, Wouters J. Clinical application of dichotic multiple-stimulus auditory steady-state responses in highrisk newborns and young children. Audiol Neurootol. 2006; 11(1):24-37. DOI:10.1159/000088852

21. Chimona Th, Kiagiadaki D, Proimos E, Seferlis F, Maroudias $\mathrm{N}$, Papadakis Ch. Auditory steady-state responses and auditory brainstem response thresholds in children. Int J Pediatr Otorhinolaryngol. 2011;75(Suppl 1):86. DOI:10.1016/S01655876(11)70440-2

22. Perez-Abalo MC, Savio G, Torres A, Martin V, Rodriguez E, Galan L. Steady state response to multiple amplitude-modulated tones: an optimized method to test frequency-specific thresholds in hearing-impaired children and normal-hearing subjects. Ear Hear. 2001;22:200-11. DOI:10.1097/00003446200106000-00004

23. Martinez-Beneito P, Ventura AM, Ribas MIP, Callejo FJG, Algarra JM. Potenciales evocados auditivos de estado estable a multifrecuencia com técnica de determinación de umbrales auditivos. Acta Otorrinolaringol Esp. 2002;53:707-17. DOI: 10.1016/S0001-6519(02)78367-2 (in Spanish)

24. Dimitrijevic A, John MS, Van Roon P, Purcell DW, Adamonis $\mathrm{J}$, Ostroff J, et al. Estimating the audiogram using multiple auditory steady-state responses. J Am Acad Audiol. 2002;13:20524. https://www.researchgate.net/publication/11346069_Estimating_the_audiogram_using_multiple_auditory_steady-state _responses

25. Rance G, Roper R, Symons L, Moody LJ, Poulis C, Dourlay $\mathrm{M}$, et al. Hearing threshold estimation in infants using auditory steady state responses. J Am Acad Audiol. 2005;16:291-300. DOI:10.3766/jaaa.16.5.4

26. Werff KRV, Brown CJ. Effect of audiometric configuration on threshold and suprathreshold auditory steady-state responses. Ear Hear. 2005;26:310-26. DOI: 10.1097/00003446-2005 06000-00007

27. Canale A, Lacilla M, Cavalot AL, Albera R. Auditory steadystate responses and clinical applications. Eur Arch Otorhinolaryngol. 2006;263:499-503. DOI:10.1007/s00405-006-0017-y

28. Fernández AM, Fernández MAA, Martínez LFA, Álvarez ABA, León MTM, Quevedo MS. Comparative study between auditory steady-state response, and auditory brainstem response and liminar tonal audiometry. Acta Otorrinolaringol Esp. 2007;58:290-5. DOI: 10.1016/S2173-5735(07)70353-8

29. Ahn JH, Lee HS, Kim YJ, Yoon TH, Chung JW. Comparing pure-tone audiometry and auditory steady state response for the measurement of hearing loss. Otolaryngol Head Neck Surg. 2007;136:966-71. DOI: 10.1016/j.otohns.2006.12.008 


\title{
Sažetak
}

\section{USPOREDBA PRAGA SLUHA DOBIVENOG POMOĆU ASSR (AUDITORY STEADY STATE RESPONSES) I RANIM AUDITIVNIM EVOCIRANIM POTENCIJALIMA KOD DJECE}

\author{
S. Lemajić-Komazec, Z. Komazec, M. Buljčik Čupić, S. Kneževići O. Vajs
}

Trenutne preporuke pedijatrijskih audiologa su da slušnu amplifikaciju kod djece treba započeti od 6. mjeseca, nakon prethodnog određivanja tipa i stupnja oštećenja sluha i audiometrijske konfiguracije. Cilj ove studije bio je usporediti rezultate dobivene pomoću ranih auditivnih evociranih potencijala (c-ABR) i ASSR (auditory steady state responses) kod djece. Ovo istraživanje je obuhvatilo 68 djece s različitim stupnjem oštećenja sluha procijenjenim pomoću c-ABR i ASSR. Poznato je da je prag sluha određen pomoću c-ABR u visokoj korelaciji s razinom sluha na $2 \mathrm{kHz}$. U našem istraživanju je korelacija između pragova sluha određenh pomoću c-ABR i ASSR u cijelom uzorku bila 0,58, 0,73, 0,97, 0,96, 0,95, 0,97; u skupini djece s c-ABR pragovima sluha do $40 \mathrm{dBHL}$ bila je $0,42,0,73,0,86,0,74,0,81,0,81$; a u skupini s c-ABR pragovima sluha nižim od $40 \mathrm{dBHL}$ bila je $0,46,0,56,0,89,0,83,0,85,0,89$ na 0,5, 1,2, 4,1-4 odnosno 2-4 kHz. Pojedinačne razlike između pragova sluha određenih pomoću c-ABR i ASSR u cijelom uzorku bile su do 95, 90, 20, $25 \mathrm{~dB}$ na 0,5, 1, 2 odnosno 4 kHz. Rezultati studije su pokazali da postoji statistički značajna korelacija između pragova sluha određenih pomoću c-ABR $\mathrm{i}$ ASSR na 2, 4, 1-4, 2-4 kHz. ASSR se može koristiti kao značajan klinički alat i odlična komplementarna metoda koja, zajedno s drugim audiološkim tehnikama, omogućava precizniju procjenu praga sluha kod djece.

Ključne riječi: Evocirani potencijali, auditivni; Audiometrija; Sluh, gubitak 